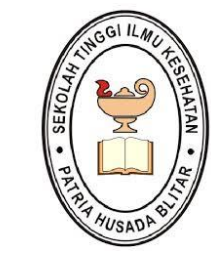

JCSH

JOURNAL OF COMMUNITY SERVICE

FOR HEALTH

http://juda.phb.ac.id/index.php/jcsh

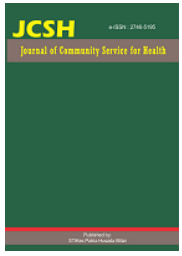

\title{
Health Education on Physical Changes in the Menopause in Jatinom Village, Kanigoro Blitar
}

\author{
Ika Agustina ${ }^{1}$, Miftah Chairunnisa ${ }^{2}$ \\ ${ }^{1,2}$ Departement of Midwifery, STIKes Patria Husada Blitar, Indonesia
}

\begin{tabular}{l} 
Article Information \\
\hline History Article: \\
Received, 15/08/2020 \\
Accepted, 06/09/2020 \\
Published, 05/11/2020 \\
\hline
\end{tabular}

Keywords:

Health Education,

Physical Change,

Menopause

\begin{abstract}
The changing of menopause times often cause discomfort or anxiety. Women who were initially active in various activities in the community can be disrupted because of various complaints caused by changes in menopause, it will be exacerbated if women do not realize that sigh are caused by physical changes during menopause. The importance of information for older women, especially women aged 48-60 years is given medical education through enlightenment on physical changes at menopause. By this health education, mothers understand better in facing the physical changes they experience. The results of the questionnaire given to mothers found that 10 menopause mothers $(83 \%)$ did not know the physical changes experienced and 2 menopause mothers (17\%) experienced changes that occurred in the mother's body. Providing good and correct education in menopause is very much needed, not just once but it must be repeated, for example, to continue to participate in the elderly posyandu activities so that mothers are aware and fell comfort with their conditions.
\end{abstract}

(C) 2020 Journal of Community Service for Health

Correspondence Address:

STIKes Patria Husada Blitar - East Java, Indonesia

E-ISSN : 2746-5195

Email: ikapatria45@gmail.com

DOI: https://doi.org/10.26699/jcsh.v1i1.ART.p001-004

This is an Open Access article under the CC BY-SA license (http://creativecommons.org/licenses/by-sa/4.0/) 


\section{INTRODUCTION}

Menopause is something that is usually faced by women when their fertility years decline, so that for some women it causes anxiety or restless, while others bring self-confidence (Suparni I, 2016). WHO and Law No. 13 of 1998 concerning the welfare of the elderly in Chapter 1 Article 1 Verse 2 states that 60 is the beginning of old age. Aging is not a disease, but it is a gradual process that in cumulative changes, but it is the lowering of the body's resistance in dealing with internal and external stimuli (Yorinda S, 2019).

Menopause changes often cause discomfort or anxiety. Women who are initially active in various activities in society can have their activities disrupted due to various complaints caused by changes in menopause, not realizing that the physical changes of the menopause period can make a woman's problem worse. Physical changes experienced by some women will experience hair loss, weight gain, sagging breasts, and skin becomes dry easily (Eko I, 2016).

The total population in terms of sex has increased every year, from 2010 to 2013. In 2010 there were $118,010,413$ female residents, in 2011 the female population was 119,768,768, in 2012 the female population was 121,553,332 residents and in 2013 the female population was 123,364,472 (Depkes RI, 2013). The results of the interviews with the Jatinom village midwife were obtained that at this time there were still some women who did not understand the situation they were experiencing, they were still confused about the physical changes that occurred during menopause.

\section{METHOD}

This community service program is carried out through outreach by providing health education about physical changes in menopause.

For the process of implementing and evaluating of the counseling results taken through a questionnaire.

\section{RESULTS}

\section{Mother's knowledge about physical changes in menopausal women}

The results of questionnaire given to mothers are found that 10 menopause mothers $(83 \%)$ did not know the physical changes experienced and 2 menopausal mothers (17\%) experienced changes that occurred in the mother's body.

In dealing with menopause, women have different understandings because this is related to several factors, such as the level of knowledge. Most women in Indonesia do not know about menopause, especially those in rural areas (FK UI, 2003). This ignorance is based on the view that menopause is a natural symptom (Nurningsih, 2012).

The menopause period is when women experience physical changes such as the heat sensation in the neck, face and chest, the mother also sweats at night, palpitations, experience insomnia, gain weight, vaginal dryness and loss of supporting tissue and genital organs. Secondary, such as the uterus, fallopian tubes, cervix, vagina, vulva, perineum and anus which eventually changes (Proverawati, 2007). Menopause is the period of cessation of menstruation that occurs in women aged 48 to 55 years. This period is very complex for women because it is related to their physical and mental condition (Baziad, 2008). 


\section{DISCUSSION}

\section{Health education about physical changes at menopause}

The menopause phase is the cessation of menstruation, physical changes begin to stand out which lasts about 3-4 years, occurring at the age of 48-60 years. In physical changes a woman experiences skin changes, the subcutaneous fat is reduced so that it becomes loose. The skin is prone to sunburn and causes pigmentation and turns black. Black spots grow on the skin. The muscles under the facial skin relax so that they fall off and are not tight. The skin glands are not functioning properly, so the skin becomes dry and wrinkled. Changes in body metabolism are marked by a decrease in the release of the hormones thyroxin and insulin, combustion, and decreased body function. To be able to adjust for the decrease in metabolism, dietary changes are made according to needs. Dietary changes are recommended for foods high in fiber. Decreasing estrogen can cause the intestinal changes to work slowly. The ability of the intestines to reabsorb food juices decreases. The slow work of the small and large intestines causes bowel disorders in the form of constipation. Changes in the heart and blood vessel systems occur due to changes in metabolism, decreased estrogen, and decreased parathyroid hormone expenditure. Increased FSH and LH hormones and low estrogen can cause changes in blood vessels. The widening of the blood vessels in the face, neck and nape causes a burning sensation called hot flushes (body feeling hot). Cholesterol buildup in the blood vessels causes coronary heart disease (Ayu I.C dkk, 2009).

In the reproductive system, the vulvar tissue becomes thinner due to the reduction and loss of fat and elastic tissue. The skin thins and blood vessels are reduced, causing shrinkage of the vulvar folds. This results in pruritus (itching) of the vulva due to atrophy, loss of skin secretions, dyspareunia (intercourse pain), wrinkling of the introitus and reduced thickness of pubic hair.

Breasts become atrophic, as well as a reduction in water milk and fibrotic. This widespread milk drain contains fluid, lacerations, and the breasts pain. Many menopause women complain of muscle and joint pain. Osteoertrosis emerged, and osteoarthritis caused by estrogen deficiency with estrogen causes damage to the collagen matrix so that cartilage is damaged by itself. Aging does not cause the heart to shrink like other organs, but hypertrophy occurs. 30-90 years of age is a period of increase heart rate ( \pm 1 gram / year in men and \pm 1.5 grams / year in women) (Eko I, 2016).

\section{CONCLUSION}

Based on the results of the evaluation of the women's menopause education, it can be concluded that the activities of counseling for menopause mothers obtained positive result, the mothers became aware of the physical changes they experienced.

\section{SUGGESTION}

From the results obtained, the problem occurs because the mother does not understand the physical changes that occur in menopause women. Mothers are expected to accept and realize that as they get older they will experience changes in themselves, namely physical changes. In order for mothers to feel comfortable with the situation they are experiencing, mothers are encouraged to exercise a little and eat healthy foods and for mothers to regularly follow the elderly posyandu to add information. 


\section{REFERENCES}

Ayu I. C dkk. (2009). Memahami Kesehatan Reproduksi Wanita, Edisi 2. Jakarta : EGC.

Baziad. M, A. (2008). Endokrinologi Ginekologi. Jakarta: Media Aesculapius

Eko, I \& Yuli R. (2016). Menopause (Masalah dan Penanganannya). Yogyakarta : CV Budi Utama.

Depkes RI. (2013). Profil Kesehatan Indonesia.

Fakultas Kedokteran Universitas Indonesia. (2003). Menopouse dan Andropouse. Jakarta: Yayasan Bina Pustaka Sarwono Prawirohardjo.

Lestari, D. (2010). Seluk Beluk Menopause. Jogjakarta : Gerai Ilmu

Nurningsih. (2012). Hubungan Tingkat Pengetahuan tentang Menopouse dengan Keluhan Wanita Saat Menopouse di Kelurahan Cijantung Kecamatan Pasar Rebo Jakarta Timur Tahun 2012. Skripsi, Program Studi Ilmu Keperawatan, Fakultas Kedokteran dan Ilmu Kesehatan, Universitas Islam Negeri Syarif Hidayatullah. Jakarta.

Suparni, I. E \& Astutik, R.Y. (2016). Menopause (Masalah dan Penanganannya). Yogyakarta : CV Budi Utama.

Yorinda, C \& Mathar, I. (2019). Menopause (Kesehatan Reproduksi Wanita Lanjut Usia). Jawa Timur : Uwais Inspirasi Indonesia. 